\title{
Prevalence and pathology of Lernaea cyprinacea (Crustacea: Lernaeidae) parasitizing tadpoles of Pelophylax bedriagae (Anura: Ranidae) in Antalya, Turkey
}

\author{
D. Innal, ${ }^{1}$ D. Sozbilen, ${ }^{2}$ and O. Ozmen ${ }^{3}$ \\ ${ }^{1}$ Burdur Mehmet Akif Ersoy University, Department of Biology. Burdur, 15030, Turkey. E-mail: innald@yahoo.com. \\ ${ }^{2}$ Pamukkale University, Acıpayam Vocational School, Department of Veterinary. Denizli, Turkey. \\ ${ }^{3}$ Burdur Mehmet Akif Ersoy University, Faculty of Veterinary Medicine, Department of Pathology. Burdur, 15030, Turkey.
}

\begin{abstract}
Prevalence and pathology of Lernaea cyprinacea (Crustacea: Lernaeidae) parasitizing tadpoles of Pelophylax bedriagae (Anura: Ranidae) in Antalya, Turkey. This is a report of the first record of the occurrence of Lernaea cyprinacea on tadpoles of Pelophylax bedriagae, a frog species native from Karpuzçay Creek, Antalya, Turkey. A total of 20 tadpoles of $P$. bedriagae were examined and $14(70 \%)$ specimens were infected. A maximum of two parasites per host was found, primarily around the cloaca. In general, slight to moderate hyperemia was noticed around the parasite. Typically, granuloma form in the tissues around the parasite. Histopathological examination revealed that hemorrhages and pathological lesions such as dermal erosions, and a chronic inflammatory reaction in skin and muscle were present at the site of parasite attachment.
\end{abstract}

Keywords: Anchor worms, disease, parasitic copepods, parasitism.

\begin{abstract}
Resumo
Prevalência e patologia de Lernaea cyprinacea (Crustacea: Lernaeidae) parasitando girinos de Pelophylax bedriagae (Anura: Ranidae) em Antalya, Turquia. Este é o relato do primeiro registro da ocorrência de Lernaea cyprinacea em girinos de Pelophylax bedriagae, uma espécie de anuro nativa de Karpuzçay Creek, Antalya, Turquia. Foram examinados 20 girinos de $P$. bedriagae, e 14 (70\%) espécimes estavam infectados. Um máximo de dois parasitas por hospedeiro foi encontrado, principalmente ao redor da cloaca. Em geral, observou-se hiperemia leve a moderada ao redor do parasita. Normalmente, o granuloma forma-se nos tecidos ao redor do parasita. O exame histopatológico revelou que hemorragias e lesões patológicas, como erosões dérmicas, e uma reação inflamatória crônica na pele e nos músculos estavam presentes no local da fixação dos parasitas.
\end{abstract}

Palavras-chave: copépodes parasitas, doença, parasitismo, vermes-âncora.

Received 11 March 2019

Accepted 03 September 2019

Distributed December 2019 


\section{Introduction}

Amphibians reflect the global decline of biodiversity (Houlahan et al. 2000, Alford et al. 2001); they are highly threatened by invasive species, over-exploitation, land-use change, climate change, increased use of pesticides, and infectious diseases (Collins and Storfer 2003). These environmental changes can affect the health of organisms by fostering the spread of diseases, such as parasitic infections. Likewise, environmental change may affect parasite transmission as a result of interactions among hosts, parasites, and biotic and abiotic conditions (Lafferty and Kuris 1999). Parasitic infections causes severe health effects, such as limb malformations (Sessions and Ruth 1990, Johnson et al. 1999, 2004, Ming 2001), and tissue damage (Martin and Conn 1990, Schotthoefer et al. 2003, Belden 2006, Holland et al. 2007). Therefore, it is important to understand the interactions of amphibians and parasites to assess the status of amphibian populations in the changing environmental conditions of today's world.

Ranid water frogs of the genus Pelophylax are distributed across the eastern Mediterranean. Three species of Pelophylax are found in Turkey-viz., P. ridibundus (Pallas, 1771), $P$. bedriagae (Camerano, 1882), and $P$. caralitanus (Arikan, 1988). The Levant Green Frog ( $P$. bedriagae) is a largely aquatic species that inhabits permanent wetlands with rich aquatic vegetation; it is categorized as a species of Least Concern (LC) with a decreasing population trend in the Red List of International Union for the Conservation of Nature (IUCN). It is widely distributed in the eastern Mediterranean (Figure 1), especially along the Aegean coasts and southern Anatolian highlands of Turkey (Papenfuss et al. 2009). Population declines of $P$. bedriagae have been reported in the western Aegen Region of Turkey (Başkale and Kaya 2012).

According to the report of Amin et al. (2012) on helminth parasites in anurans from Turkey, the most heavily infected species was Pelophylax ridibundus. Demir et al. (2015) is the first report of helminth parasites in $P$. bedriagae from western Aegean Region in Turkey. Düşen and Öz (2006) also reported helminth infections in $P$. ridibundus (= Rana ridibunda) from Antalya; however, these frogs were more likely belonging to $P$. bedriagae, considering the distribution range of the species. Infections of parasites other than helminths have not been reported in $P$. bedriagae. Although infections of Lernaea cyprinacea Linnaeus, 1758 are documented for adult and larval anurans worldwide (Baur 1962, Martins and Souza 1996, Alcalde and Batistoni 2005, Kupferberg et al. 2009, Salinas et al. 2016), the parasite has not been reported in anurans from Turkey.

Herein, we describe a parasitic copepod infection in larvae of Pelophylax bedriagae and the histopathological effects of the parasite on infection areas. We also consider the possible effects of the parasite on populations of $P$. bedriagae in response to future environmental changes.

\section{Materials and Methods}

Larvae of Pelophylax bedriagae were collected with a dip net on 07 October 2017 from Karpuzçay Creek (36 42'56.84" N, $31^{\circ} 33^{\prime} 0.95^{\prime \prime} \mathrm{E}$; Figure 1), which flows into the Antalya Gulf (Mediterranean Sea, Turkey). Immediately after collection, the tadpoles during were examined for the presence of Lernaea cyprinacea, which subsequently was identified in the laboratory with a dissecting microscope and Bauer (1987) as a reference. The terms prevalence (percentage of hosts infected with a particular parasite species or taxonomic group) and intensity (number of individuals of a parasite species in/on a single infected host) are used sensu Bush et al. (1997).

Tissue samples were collected during the necropsy. Transverse sections of areas where parasites were attached cut and fixed in $10 \%$ 


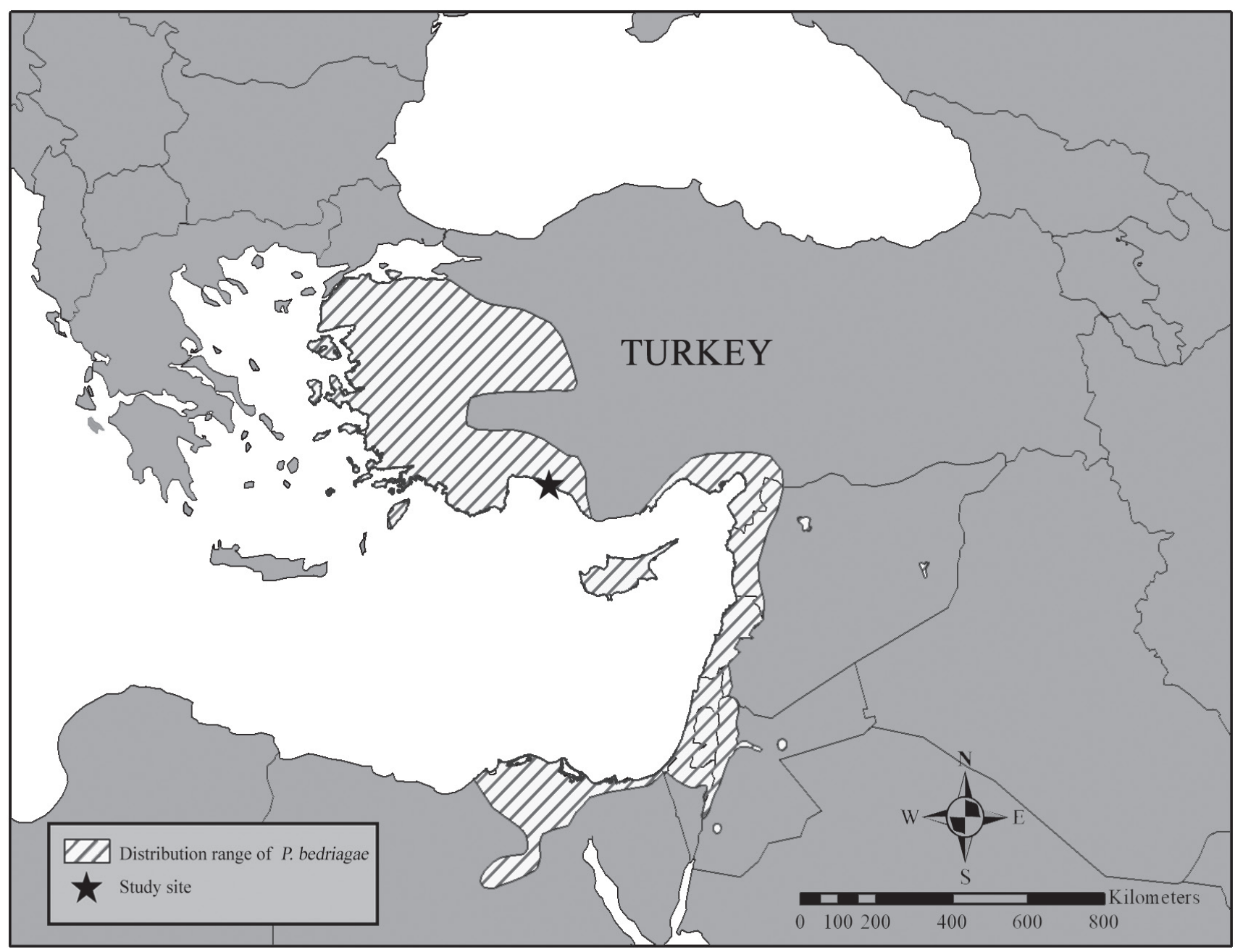

Figure 1. Distribution of Pelophylax bedriage and the study site (indicated by *) at Karpuzçay Creek, Antalya-Turkey.

neutral formalin for histopathological studies. After routine processing of the formalin-fixed samples using automatic tissue processing equipment (Leica ASP300S; Leica Microsystem, Nussloch, Germany), the samples were embedded in paraffin, and 5- $\mu \mathrm{m}$ serial sections of the attached parasite bodies were prepared with a Leica RM 2155 rotary microtome (Leica Microsystem, Nussloch, Germany). These sections were stained with hematoxylin and eosin (HE) and examined under light microscope. Morphometric evaluation and microphotography were performed using the Database Manual cellSens Life Science Imaging Software System (Olympus Corporation, Tokyo, Japan).

\section{Results}

Of the 20 larvae of Pelophylax bedriagae that were examined, 14 (70\%) were infected by Lernaea cyprinacea (Figure 2). A total of $16 \mathrm{~L}$. cyprinacea were obtained from the 14 parasitized tadpoles. A mean intensity of 1.14 L. cyprinacea with 1 or 2 specimens per host was recorded; $63.5 \%$ were attached around the tadpole cloaca, with the remaining parasites being attached elsewhere on the body.

Usually, the larval tissue around the parasite is grossly hyperemic. Histopathological examination reveals obvious pathological lesions in the area of parasite attachment. Microscopical 
examination of sections revealed that the lesions are located in the epidermis, dermis, and muscles. Typically, ulcers are found in the epidermis at the site of parasite attachment (Figure $3 \mathrm{~A}-\mathrm{C}$ ). In most cases, the epidermis presented mild to severe acanthosis and spongiosis around the parasite. The most common symptom in the subdermal muscle is a chronic inflammatory reaction. In response to the presence of the parasite, there are infiltrated groups of cells that primarily comprise lymphocytes, histiocytes, and eosinophils. Fibrous tissue formation and granuloma-like lesions are common at the sites of parasite attachment. Chronic granulomatous myositis characterized by degenerative or, in some cases, necrotic lesions were noted in skeletal muscles (Figure 3 D-F). Other lesions in skin and muscle tissues are edema, congestion and small hemorrhages were also observed.

\section{Discussion}

In this study, we reported the first record and description of the parasitic infection of Lernaea cyprinacaea on Pelophylax bedriagae in Turkey and also in its known distribution range. Parasites can affect populations of anurans, the sizes of which may decrease resulting from infectious diseases caused by fungi, viruses, and parasites (Murray and Skerratt 2012). Little is known about amphibian diseases and parasitic infections in Turkey. The anchor worm, L. cyprinacea, is a parasitic copepod that lives in freshwater. The host range of $L$. cyprinacea is wide (Hassan 2008, Avenant-Oldewage 2012), and infections can cause pathologies, developmental malformations, and death in fish and amphibian hosts (Avenant-Oldewage 2012, Kupferberg et al. 2009). The mortality can occur by hemorrhages, ulcerations, and secondary infections (Salinas et al. 2016). Infections of $L$. cyprinacea had been reported only in species of fish in Turkey (Geldiay and Balık 1974, Burgu et al. 1988, Innal and Avenant-Oldewage 2012, Innal et al. 2017). Since the first description of L. cyprinacea in Turkey, several studies have

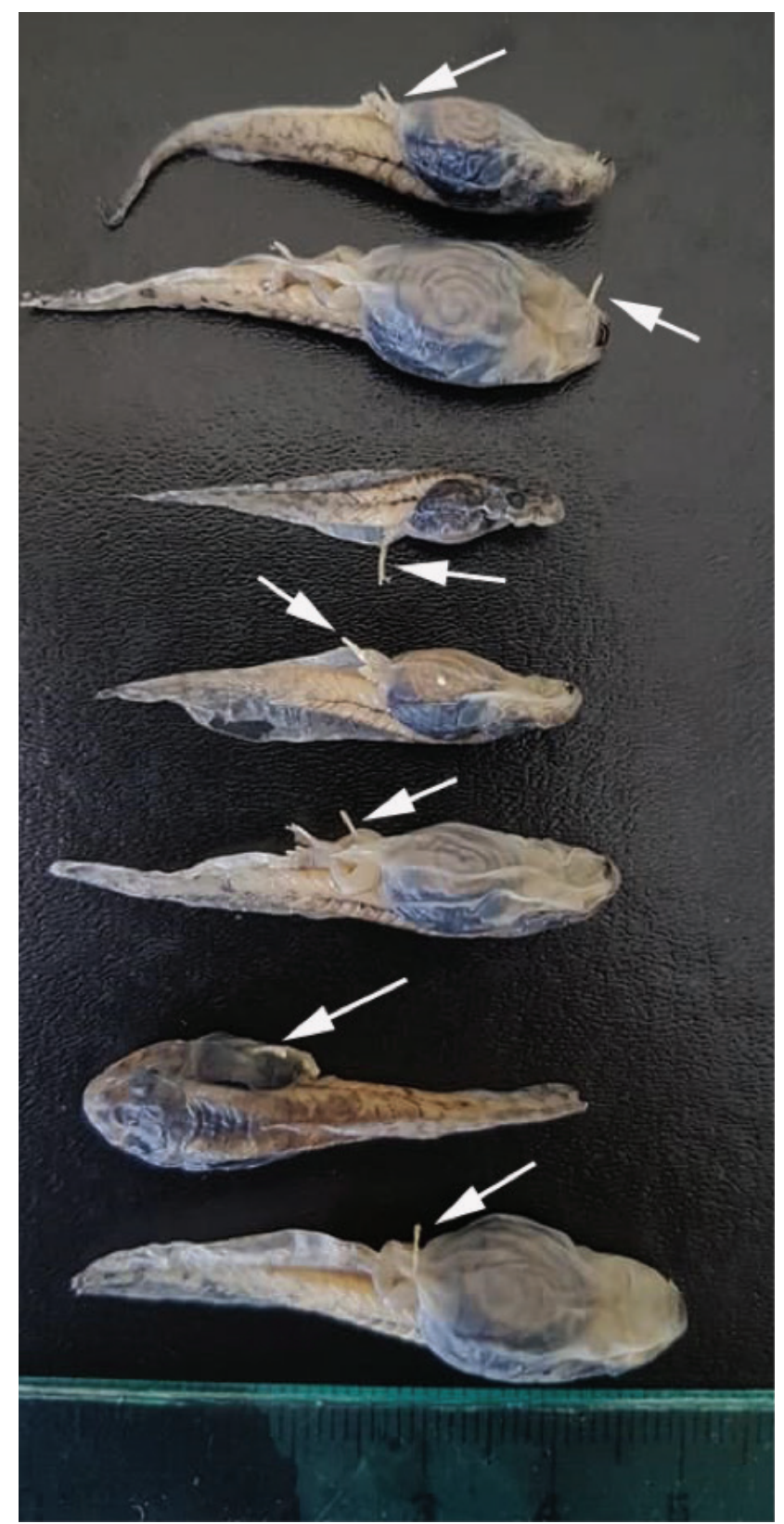

Figure 2. Pelophylax bedriage parasitized by anchor worm Lernaea cyprinacea (arrows).

demonstrated that the parasite is widespread and it has been identified as a possible threat to the native fish stocks. Our pathological findings were in agreement with those of previous studies.

The prevalence and mean intensity levels of Lernaea cyprinacea in Pelophylax bedriagae from Karpuzçay Creek were $70 \%$ and 1.14 parasites per infected tadpoles, respectively. 




Figure 3. Histopathological appearance of the sites of parasite attachment. (A) Parasite section (arrow) and inflammatory reaction (arrow head) with ulcer (thin arrow) in the skin of the young frog, HE, Bar = $100 \mu \mathrm{m}$. (B) Parasite (arrow) attached to the abdominal skin causing marked inflammatory reaction (arrow head), gut and liver section, HE, Bar $=100 \mu \mathrm{m}$. (C) Parasite (arrow) and inflammation (arrow head, HE, Bar $=100 \mu \mathrm{m}$. (D) Two granulomas (arrow heads) in muscle, HE, Bar $=100 \mu \mathrm{m}$. (E) Marked inflammatory reaction composed by mononuclear cells and eosinophil leucocytes (arrow head) around the parasite (arrow), HE, Bar $=50 \mu \mathrm{m}$. (F) Higher magnification of the classical granuloma and fibrous tissue (arrow head) around the parasite, $\mathrm{HE}, \mathrm{Bar}=20 \mu \mathrm{m}$. 
Levels of L. cyprinacea infestation in anuran species are highly variable, with a prevalence of 9.2\% in 2006 and $10.5 \%$ in 2008 in Rana boylii Baird, 1854 in Northern California (Kupferberg et al. 2009). The prevalence of the parasite in Lithobates catesbeianus (Shaw, 1802) from the Río de los Sauces and Toledo Stream in Argentina was reported to be $53.3 \%$ and $58.33 \%$, respectively (Salinas et al. 2016).

A general decreasing population sizes of Peylophylax bedriagae (Papenfuss et al. 2009) has been reported in Turkey (Başkale and Kaya 2012). We have demonstrated that Lernaea cyprinacaea has an adverse effect on the health of members of the population of $P$. bedriagae from Karpuzçay Creek. It has been long known that changing environmental conditions influence parasite-host interactions. Kupferberg et al. (2009) suggested that changing hydrology during the warm periods followed by lowered water levels and reduced daily discharge may expose high densities of frog larvae to parasite transmission. Increased prevalence of parasite infection may cause a reduction in individuals host fitness, and eventually may reduce the survival rates. Anthropogenic environmental changes have led to increased prevelance of diseases and the global decline in amphibians; clearly, further studies are required to understand the complex interactions between parasites and their amphibian hosts.

\section{Acknowledgments}

We thank anonymous reviewers for their constructive corrections as well to Linda Trueb for the English correction and her comments. We are grateful to Ayhan Şahin for laboratory assistance, and thank Kerem Atatunç (Burdur Mehmet Akif Ersoy University) for field assistance.

\section{References}

Alcalde, L. and P. Batistoni. 2005. Hyla pulchella cordobae (Cordoba tree frog) parasitism. Herpetological Review 36: 302.
Alford, R. A., P. M. Dixon, and J. H. K. Pechmann. 2001. Global amphibian population declines. Nature 414: 449-500.

Amin, O. M., S. Düşen, and M. C. Oğuz. 2012. Review of the helminth parasites of Turkish anurans (Amphibia). Scientia Parasitologica 13: 1-16.

Avenant-Oldewage, A. 2012. Lernaea and related species. Pp. 337-349 in P. T. K. Woo and K. Buchmann (eds.), Fish Parasites Pathobiology and Protection. Oxfordshire. CABI.

Başkale, E. and U. Kaya. 2012. Decline of the Levantine Frog, Pelophylax bedriagae Camerano, 1882, in the western Aegean Region of Turkey changes in population size and implications for conservation. Zoology in the Middle East 57: 69-76.

Bauer, O. N. 1987. Guide for Identification of Parasites of the Freshwater Fish Fauna of the USSR. Vol 3. Leningrad. Zoological Institute, Academy of Sciences of the USSR. 583 pp.

Baur, O. N. 1962. Parasites of Freshwater Fish and the Biological Basis for thier Control. Bulletin of the State Scientific Research Institute of Lake and River Fisheries 49: $108-112$.

Belden, L. K. 2006. Impact of eutrophication on wood frog, Rana sylvatica, tadpoles infected with Echinostoma trivolvis cercariae. Canadian Journal of Zoology 84: 1315-1321.

Burgu, A., T. Oğuz, W. Korting, and N. Güralp. 1988. Parasites of freshwater fishes in some areas of Central Anatolia. Journal of Etlik Veterinary Microbiology 6: $143-165$.

Bush, A. O., K. D. Lafferty, J. M. Lotz, and A. W. Shostak. 1997. Parasitology meets ecology on its own terms: Margolis et al., Revisited. Journal of Parasitology 83: $575-583$.

Collins, J. P. and A. Storfer. 2003. Global amphibian declines: sorting the hypotheses. Diversity and Distributions 9: 89-98.

Demir, S., O. Yakar, H. S. Yıldırımhan, and S. Birlik. 2015. Helminth parasites of the levantine frog (Pelophylax bedriagae Camerano, 1882) from the western part of Turkey. Helminthologia 52: 71-76.

Düşen, S. and M. Öz. 2006. Helminths of the Marsh Frog, Rana ridibunda Pallas, 1771 (Anura: Ranidae), from Antalya Province, Southwestern Turkey. Comparative Parasitology 73: 121-129.

Geldiay, R. and S. Balık. 1974. Ecto and Endoparasites found the freshwater fish of Turkey. Ege University Science Faculty Monographies 14: 1-34. 
Hassan, M. 2008. Parasites of native and exotic freshwater fishes in the South-west of Western Australia. Unpublished PhD. Thesis. Murdoch University, Australia.

Holland, M. P., D. K. Skelly, M. Kashgarian, S. R. Bolden, L. M. Harrison, and M. Cappello. 2007. Echinostome infection in green frogs (Rana clamitans) is stage and age dependent. Journal of Zoology 271: 455-462.

Houlahan, J. E., C. S. Findlay, B. R. Schmidt, A. H. Meyer, and S. L. Kuzmin. 2000. Quantitative evidence for global amphibian population declines. Nature 404: $752-$ 755 .

Innal, D. and A. Avenant-Oldewage. 2012. Occurrence of Lernaea cyprinacea on mosquito fish (Gambusia affinis) from Kundu Estuary (Antalya-Turkey). Bulletin of the European Association of Fish Pathologists 32: 140147.

Innal D, A. Avenant-Oldewage, B. Dogangil, M. M. Stavrescu-Bedivan, O. Ozmen, and S. Mavruk. 2017. Susceptibility of endemic and non-indigenous fish to Lernaea cyprinacea (Copepoda: Lernaeidae): a case study from Düger Spring Creek (Burdur-Turkey). Bulletin of the European Association of Fish Pathologists 37: 96-105.

Johnson, P. T. J., K. B. Lunde, E. G.. Ritchie, and A. E. Launer. 1999. The effect of trematode infection on Amphibian limb development and survivorship. Science 284: 802-804.

Johnson, P. T. J., D. R. Sutherland, J. M. Kinsella, and K. B. Lunde. 2004. Review of the trematode genus Ribeiroia (Psilostomidae): ecology, life history and pathogenesis with special emphasis on the amphibian malformation problem. Advances in Parasitology 57: 191-253.

Kupferberg, S. J., A. Catenazzi, K. Lunde, A. J. Lind, and W. J. Palen. 2009. Parasitic copepod (Lernaea cyprinacea) outbreaks in Foothill Yellow-legged frogs (Rana boylii) linked to unusually warm summers and amphibian malformations in northern California. Copeia 2009: 529-537.
Lafferty, K. D. and A. M. Kuris. 1999. How environmental stress affects the impacts of parasites. Limnology and Oceanography 44: 925-931.

Martin, T. R., D. B. Conn. 1990. The pathogenicity, localization, and cyst structure of echinostomatid metacercariae (Trematoda) infecting the kidneys of the frogs Rana clamitans and Rana pipiens. Journal of Parasitology 76: 414-419.

Martins, M. L. and F. L. D. J. Souza. 1996. Experimental infestations of Rana catesbeiana Shaw tadpoles by copepodids Lernaea cyprinacea Linnaeus (Copepoda, Lernaeidae). Revista Brasilera de Zoologia 12: 619625.

Ming, L. T. 2001. Parasitic copepods responsible for limb abnormalities? Froglog 46: 2-3

Murray, K. A. and L. F. Skerratt. 2012. Predicting wild hosts for amphibian chytridiomycosis: integrating host lifehistory traits with pathogen environmental requirements. Human and Ecological Risk Assessment 18: 200-224.

Papenfuss, T., S. Kuzmin, A. M. Disi, G. Degani, I. H. Ugurtas, M. Sparreboom, S. Anderson, R. Sadek, S. Hraoui-Bloquet, A. Gasith, E. Elron, S. Gafny, P. Lymberakis, W. Böhme, and S. Baha El Din. 2009. Pelophylax bedriagae. The IUCN Red List of Threatened Species 2009: e.T58559A86622844.

Salinas, Z. A., F. G. Biolé, P. R. Grenat, F. E. Pollo, N. E. Salas, and A. L. Martino. 2016. First report of Lernaea cyprinacea (Copepoda: Lernaeidae) in tadpoles and newly-metamorphosed frogs in wild populations of Lithobates catesbeianus (Anura: Ranidae) in Argentina. Phyllomedusa 15: 43-50.

Schotthoefer, A. M., R. A. Cole, and V. R. Beasley. 2003. Relationship of tadpole stage to location of echinostome cercariae encystment and the consequences for tadpole survival. Journal of Parasitology 89: 475-482.

Sessions, S. K. and S. B. Ruth. 1990. Explanation for naturally occurring supernumerary limbs in amphibians. Journal of Experimental Zoology 254: 38-47. 